\title{
A MASS SPECTROMETRIC STUDY OF PEDICULARINE AND ITS METHYL ESTER
}

S. Khakimdzhanov, A. Abdusamatov, and S. Yu. Yunusov

Khimiya Prirodnykh Soedinenii, Vol. 6, No. 1, pp. 142-143, 1970

UDC 547.944/945

The mass spectrum of pedicularine (I) [1] has the peaks of ions with $\mathrm{m} / \mathrm{e} 177(52 \%), 162(100 \%), 133(40 \%), 118$ $(68 \%), 117(52 \%), 91(34 \%)$ and $77(14 \%)$. The fragmentation of the molecular ion $\left(\mathrm{M}^{+}, 177\right)$ takes place mainly in two directions.

First direction: A methyl group is eliminated from the molecular ion with m/e 177, and the maximum ion with $\mathrm{m} / \mathrm{e} 162$ appears, which loses a hydrogen atom and gives an ion with $\mathrm{m} / \mathrm{e} 161$. A molecule of $\mathrm{CO}_{2}$ splits out from the latter forming an ion with $\mathrm{m} / \mathrm{e} 117$.

Second direction: Fragmentation begins with the splitting out of $\mathrm{CO}_{2}$ from the molecular ion; an ion with $\mathrm{m} / \mathrm{e}$ 133 is formed which is converted by the elimination of a methyl radical into an ion with $\mathrm{m} / \mathrm{e} 118$.

The mass spectrum of the methyl ester of pedicularine (II) has peaks of ions with $\mathrm{m} / \mathrm{e} 191(100 \%), 176(88 \%), 161$ $(22 \%), 146(20 \%), 118(39 \%), 117(22 \%), 91(13 \%)$, and $77(11 \%)$. The molecular ion forms the maximum peak $\left(\mathrm{M}^{+}, 191\right)$ and is converted by the loss of a methyl radical into an ion with $\mathrm{m} / \mathrm{e} 176$. Then the ion with $\mathrm{m} / \mathrm{e} 176 \mathrm{loses}$ a $\mathrm{CH}_{3} \mathrm{OOC}$ group, being converted into a fragment with $\mathrm{m} / \mathrm{e} 117$. Another fragmentation route begins with the splitting out of an $\mathrm{OCH}_{2}$ group from the molecular ion $\left(\mathrm{M}^{+}, 191\right)$ and the formation of an ion with $\mathrm{m} / \mathrm{e} 161$, which, by losing a $\mathrm{CH}_{3}$ group, is converted into an ion with $\mathrm{m} / \mathrm{e} 146$. The ejection of a $\mathrm{CO}$ group from the ion with $\mathrm{m} / \mathrm{e} 146$ leads to an ion with $\mathrm{m} / \mathrm{e}$ 118. Then the ion with $\mathrm{m} / \mathrm{e} 118$ loses a hydrogen atom and is converted into a fragment with $\mathrm{m} / \mathrm{e} 117$.

The further fragmentation of I and II takes place similarly to that of indicaine and plantagonine [2].

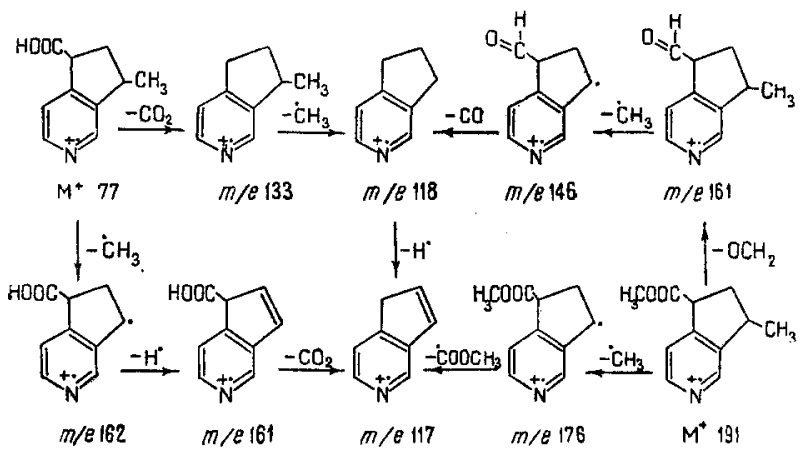

The mass spectra were taken on an MKh-1303 instrument at $95^{\circ} \mathrm{C}$ with an ionization energy of $40 \mathrm{eV}$.

\section{REFERENCES} 457,1969

1. A. Abdusamatov, S. Khakimdzhanov, and S. Yu. Yunusov, KhPS [Chemistry of Natural Compounds], 5,

2. A. Abdusamatov and S. Yu. Yunusov, KhPS [Chemistry of Natural Compounds], 4, $392,1968$.

8 October 1969

Institute of the Chemistry of Plant Substances, AS UzSSR 